\title{
Sexual dysfunction in women during COVID-19 pandemic: A hospital-based, prospective, cross- sectional comparative study
}

\section{COVID-19 pandemisi sırasında kadınlarda cinsel işlev bozukluğu: Hastane bazlı, prospektif, kesitsel} karşılaştırmalı çalışma

İrem Alyazıcı Küçuỉkyılldız

Sivas Cumhuriyet University School of Medicine, Department of Obstetrics and Gynecology, Sivas, Turke

Corresponding author: İem Alyazıcı Küçükyıldız, MD, Sivas Cumhuriyet University School of Medicine, Department of Obstetrics and Gynecology, Sivas, Turkey

E-mail: iremalyazici@hotmail.com

Received/Accepted: July 23, 2021 / August 20, 2021

Conflict of interest: There is not a conflict of interest.

\section{SUMMARY}

Objective: International studies have shown that overall sexual activity and frequency of sexual intercourse decreased significantly during the COVID19 pandemic. The aim of this study is to compare the female sexual dysfunction (FSD) rate in women during the COVID-19 pandemic in tertiary hospital in Turkey.

Method: A total of 150 participants who were 50 pregnant women (group I), 50 healthcare women (group II) and 50 other women (group III), participated in study. A female sexual function index (FSFI) questionnaire was applied to the women along with the questions of age, education level, delivery methods, smoking, employment status and socioeconomic levels. The sexual dysfunction rate and female sexual function index scores between the groups were compared.

Results: The median FSFI score was 23.50 in the present study population. Median scores were 22.1, 26.5, and 23.1 for groups I (pregnant), II (healthcare workers) and III (others), respectively. When the FSFI scores of the groups were compared, the FSFI score of group II was statistically significantly higher than the other groups (p: 0,001). By using the cutoff FSFI score of 26.55, $68.7 \%$ (n:103) of women were diagnosed as having sexual dysfunction. The rates of sexual dysfunction as follows $84 \%, 52 \%$, and $70 \%$ for groups I, II and III, respectively. When analyzed with FSFI domains one by one, it was seen that Group 2 had a statistically significantly higher FSFI score in the areas of Arousal, Lubrication, Orgasm, and Pain compared to the other groups.

Conclusions: The prevalence of FSD in Turkey increased during COVID19 pandemic. When comparing female sexual dysfunction prevalence in groups, the lowest sexual dysfunction prevalence was found in healthcare workers. Prevalence of sexual dysfunction was found to be associated with women's employment and educational status.

Keywords: Sexual dysfunction, healthcare women, pregnant, COVID-19, Turkey
ORCID IDs of the authors: İ.A.K. 0000-0002-6604-0713 
Amaç: Uluslararası çalışmalar, COVID-19 pandemisi sırasında genel cinsel aktivitenin ve cinsel ilişki sıklı̆̆ının önemli ölçüde azaldığını göstermiştir. Bu çalışmanın amacı, Türkiye'de üçüncü basamak bir hastanede COVID-19 pandemisi sırasında kadınlarda kadın cinsel işlev bozukluğu (FSD) oranını karşılaştırmaktır.

Yöntem: Çalışmaya 50 gebe (grup I), 50 sağlık çalışanı (grup II) ve 50 gebe ve sağlık çalışanı olmayan kadın (grup III) olmak üzere toplam 150 katılımcı katıldı. Kadınlara yaş, eğitim düzeyi, doğum şekli, sigara kullanımı, çalışma durumu ve sosyoekonomik düzey sorularının yanı sıra kadın cinsel işlev indeksi (FSFI) anketi uygulandı. Gruplar arasında cinsel işlev bozukluğu oranı ve kadın cinsel işlev indeksi puanları karşılaştıııldı.

Bulgular: Bu çalışma popülasyonunda medyan FSFI skoru 23.50 idi. Grup I (hamile), II (sağlık çalışanları) ve III (diğerleri) için medyan puanlar sırasıyla 22.1, 26.5 ve 23.1 idi. Grupların FSFI puanları karşıllaştırıldığında, grup II'nin FSFI puanı diğer gruplara göre istatistiksel olarak anlamlı derecede yüksekti (p: 0,001). 26.55 sinır FSFI puanı olarak değerlendirildiğinde, kadınların \%68.7'sine (n:103) cinsel işlev bozukluğu tanısı kondu. Grup I, II ve III için cinsel işlev bozukluğu oranları sırasıyla \%84, \%52 ve \%70'dir. FSFI alanları tek tek incelendiğinde Grup 2'nin Uyarılma, Yağlanma, Orgazm ve Ağrı alanlarında diğer gruplara göre istatistiksel olarak anlamlı derecede yüksek FSFI puanına sahip olduğu görüldü.

Sonuç: COVID-19 pandemisi sırasında Türkiye'de FSD prevalansı artmıştır. Gruplarda kadın cinsel işlev bozukluğu prevalansı karşılaştırıldığında, en düşük cinsel işlev bozukluğu prevalansı sağlık çalışanlarında bulundu. Cinsel işlev bozukluğu yaygınlığının kadınların istihdamı ve eğitim durumu ile ilişkili olduğu bulundu.

Anahtar sözcükler: Seksüel disfonksiyon, sağlık çalışanı kadınlar, hamile, COVID-19, Türkiye

\section{INTRODUCTION}

At the end of 2019, a new coronavirus (SARS $\mathrm{CoV}-2$ ) was identified as the cause of a series of pneumonia cases in Wuhan, China. It first caused an epidemic across China, and then quickly spread to the world, and the World Health Organization reported COVID-19 (Coronavirus Disease 2019) as a global pandemic in March $2020^{1}$. The pandemic brought with it many restrictions that can cause physical and psychological effects such as social isolation and quarantine. In a study investigating how people felt after the COVID-19 outbreak in the Turkish population, it was observed that $78 \%$ felt worried, $48 \%$ insecure, $42 \%$ complicated, and $34 \%$ fear and panic ${ }^{2}$. As it is known, anxiety disorder, depression and emotional or environmental stress are among the etiology and risk factors of sexual dysfunction ${ }^{3}$. Therefore, it is predicted that sexual life may also be indirectly affected by the pandemic process. Apart from psychological effects such as stress and depression, sexual dysfunctions are also associated with demographic conditions such as age, pregnancy status, education and employment ${ }^{3,4}$.

While it has been reported in the studies that approximately $43 \%$ of women living in the United States have sexual problems, Female Sexual Dysfunction (FSD) rate in Turkey has been reported to be approximately $48 \%{ }^{5,6,7}$.

In this study, we wanted to compare the FSD rates in pregnant women, healthcare workers and other women (they are not pregnant and not a health worker) during the COVID-19 pandemic in tertiary hospitals in Turkey.

\section{MATERIAL AND METHODS}

This cross sectional prospective study was performed between November 2020 and January 2021, during the COVID-19 pandemic in tertiary hospital in Turkey. This study was approved by the Human Research Ethics Committee of Sivas Cumhuriyet University (registry no: 2020-11/10)

A total of 150 women participated in our study, 50 were pregnant women who were followed up in our hospital (group I), 50 female healthcare workers (doctor, nurse and midwife) working in our hospital (group II) and 50 were non-pregnant and non-healthcare workers (group III). All women included in our study were sexually active. Women who were sexually inactive, had a history of pelvic surgery, cancer, chronic pelvic pain were excluded from the study. Pregnant women who were considered to have a high risk pregnancy and experience conditions such as bleeding, risk of miscariage, preterm birth were excluded from the study. In addition, women who had Covid -19 infection in the last month were excluded from the study. Written consent from each participant was obtained and the participants were invited to complete the questionnaire. The women completed the questionnaires alone. Women first answered questions about their demographic characteristics and then filled out the Female Sexual Function Index (FSFI) form, which consists of 19 questions to question their sexual functions ${ }^{8}$. Demographic data included age, gestational status, gravida, delivery method, smoking, educational status, employment and socioeconomic status.

FSFI form was prepared by Rosen et al. for evaluating the female sexual dysfunction ${ }^{8}$. The 
Turkish version of this form is also available and has been validated for Turkish society ${ }^{9}$. In this form, which can be applied to those who have had sexual intercourse in the last 1 month, 6 subsections are questioned, these are respectively; sexual desire, arousal, lubrication, orgasm, satisfaction and sexual pain. The scores obtained in the domains are multiplied by their coefficient and the domains and the total score are obtained and the minimum score to be obtained from the questionnaire is calculated as 2 and the maximum score 36. (Table 1) Low score in FSFI query indicates low function. Wiegel et al. stated that a total FSFI score of less than 26.55 is considered sexual dysfunction ${ }^{10}$. According to the Turkey Demographic and Health Survey pregnancy rate specified to consider, "sample calculation in cases with known prevalence ' as performed ${ }^{11}$. Analyses were performed and interpreted with $95 \%$ confidence and $94.7 \%$ study power.

Table 1: FSFI domain scores

\begin{tabular}{|l|l|l|l|l|l|}
\hline & Question & Score range & Coefficient & Min score & Max Score \\
\hline Sexual desire & 1,2 & $1-5$ & 0.6 & 1.2 & 6 \\
\hline Arousal & $3,4,5,6$ & $0-5$ & 0.3 & 0 & 6 \\
\hline Lubrication & $7,8,9,10$ & $0-5$ & 0.3 & 0 & 6 \\
\hline Orgasm & $11,12,13$ & $0-5$ & 0.4 & 0 & 6 \\
\hline Satisfaction & $14,15,16$ & 0 (or 1$)-5$ & 0.4 & 0.8 & 6 \\
\hline Sexual pain & $17,18,19$ & $0-5$ & 0.4 & 0 & 6 \\
\hline
\end{tabular}

Statistical evaluation was made with the SPSS 22 software program. For the evaluation of the questionnaire scores, normality was evaluated using the Shapiro-Wilk Test. It was observed that there was no normal distribution in the overall questionnaire and in the subgroups of the questionnaire. The demographic data changes of the groups were analyzed with the chi-square test. The differences in demographic data for the whole questionnaire and domains were analyzed with Mann Whitney U and Kruskal-Wallis tests. All of the questionnaire and its domains were compared with participant age and gestational week variables using Spearman Correlation Analysis. Statistical significance level was accepted as $\mathrm{p}<0.05$.

\section{RESULTS}

The questionnaire was applied to a total of 150 women in present study. Participants were divided into three groups. The first group consisted of pregnant women, the second group consisted of healthcare workers, and the third group consisted of women who were not pregnant and also not healthcare workers.

When the evaluation of the median ages of the groups, the median age of group I was 30 (18-40), and the median age of group II was 36 (24-53), and the median age of group III was 33 (18-49). The age of the participants was compared between the groups, it was determined that the median age of group 1 was statistically significantly lower than the other groups, and the mean age of group 2 was statistically significantly higher than the other groups (p: 0,001). (Table 2)

When the demographic data and descriptive characteristics of the groups were compared, the rate of cesarean delivery, the rate of working women and the rate of women with university education were found to be statistically significantly higher in group 2 compared to the other groups (Table 3).

The median FSFI score was 23.50 $8.2(2-35.7)$ in the present study population. By using the cutoff FSFI score of 26.55 . $84 \%(\mathrm{n}: 42)$ Group I. $52 \%$ (n:26) Group II. and 70\% (n:35) Group III women were diagnosed as having sexual dysfunction. When the FFSI scores of the groups were compared. the FSFI score of group II was statistically significantly higher than the other groups (p: 0.001). The lowest FSFI score was detected in group I. Table 4 shows the scores for each domain and total FSFI score of the study population.

When the study groups were analyzed one by one with the FSFI domains. it was found that Group 2 had a statistically significantly higher FSFI score in the Arousal. Lubrication. Orgasm. Pain domains compared to the other groups (Table 4).

When FSFI total score was compared with demographic data, it was found that education status and having employment affected FSFI score. FSFI score was found to be statistically significantly higher in having employment women, women with university or graduate education. The 
FSFI score of unemployed women was 22.80 , while the FSFI score of working women was 24.40 (p: 0.042). Additionally, higher scores were found in Arousal, Orgasm and Pain domains among working women, and women with university education. It was found that the delivery method, which is one of the demographic variables, did not affect the total FSFI score, but only the sexual pain, which is one of the FSFI areas. Sexual pain was higher in women who gave birth vaginal deliveries compared to women who gave birth by cesarean section (p: 0.046).

Table 2: Comparison of Median Ages of Groups

\begin{tabular}{|l|l|l|l|l|l|l|}
\hline \multicolumn{2}{|c|}{} & Percentile 25 & Percentile 75 & Median & IQR & $\mathrm{p}$ \\
\hline \multirow{3}{*}{ Group } & Grup I & 26,00 & 30,00 & 30,00 & 4,00 & \multirow{6}{*}{0,001} \\
\cline { 2 - 6 } & Grup II & 30,00 & 40,00 & 36,00 & 10,00 & \multirow{2}{*}{} \\
\cline { 2 - 6 } & Grup III & 29,00 & 38,00 & 33,00 & 9,00 & \\
\hline
\end{tabular}

IQR: Interquartile Range

Table 3: Demographic data and descriptive characteristics of the groups

\begin{tabular}{|c|c|c|c|c|c|c|c|c|}
\hline & \multicolumn{2}{|c|}{ Grup I } & \multicolumn{2}{|c|}{ Grup II } & \multicolumn{2}{|c|}{ Grup III } & \multirow{2}{*}{$\mathrm{p}$} \\
\hline & & $\mathrm{N}$ & $\%$ & $\mathrm{~N}$ & $\%$ & $\mathrm{~N}$ & $\%$ & \\
\hline \multirow[t]{6}{*}{ Gravida } & .00 & 0 & $0.0 \%$ & 6 & $35.3 \%$ & 11 & $64.7 \%$ & \multirow{6}{*}{0.066} \\
\hline & 1.00 & 18 & $41.9 \%$ & 13 & $30.2 \%$ & 12 & $27.9 \%$ & \\
\hline & 2.00 & 18 & $32.1 \%$ & 22 & $39.3 \%$ & 16 & $28.6 \%$ & \\
\hline & 3.00 & 10 & $50.0 \%$ & 5 & $25.0 \%$ & 5 & $25.0 \%$ & \\
\hline & 4.00 & 2 & $22.2 \%$ & 3 & $33.3 \%$ & 4 & $44.4 \%$ & \\
\hline & 5.00 & 1 & $50.0 \%$ & 1 & $50.0 \%$ & 0 & $0.0 \%$ & \\
\hline \multirow{3}{*}{ Methods of delivery } & Cesarean section & 8 & $17.0 \%$ & 29 & $61.7 \%$ & 10 & $21.3 \%$ & \multirow{3}{*}{0.001} \\
\hline & Vaginal delivery & 20 & $40.0 \%$ & 10 & $20.0 \%$ & 20 & $40.0 \%$ & \\
\hline & Both & 2 & $18.2 \%$ & 2 & $18.2 \%$ & 7 & $63.6 \%$ & \\
\hline \multirow[t]{2}{*}{ Smoking status } & no smoker & 42 & $35.6 \%$ & 38 & $32.2 \%$ & 38 & $32.2 \%$ & \multirow{2}{*}{0.53} \\
\hline & smoker & 8 & $25.0 \%$ & 12 & $37.5 \%$ & 12 & $37.5 \%$ & \\
\hline \multirow[t]{2}{*}{ Education status } & $\begin{array}{l}\text { High school and } \\
\text { below }\end{array}$ & 35 & $49.3 \%$ & 1 & $1.4 \%$ & 35 & $49.3 \%$ & \multirow{2}{*}{0.003} \\
\hline & University & 15 & $19 \%$ & 49 & $62 \%$ & 15 & $19 \%$ & \\
\hline \multirow[t]{3}{*}{ Socioeconomic status } & low & 2 & $33.3 \%$ & 0 & $0.0 \%$ & 4 & $66.7 \%$ & \multirow{3}{*}{0.25} \\
\hline & middle & 45 & $34.6 \%$ & 45 & $34.6 \%$ & 40 & $30.8 \%$ & \\
\hline & high & 3 & $21.4 \%$ & 5 & $35.7 \%$ & 6 & $42.9 \%$ & \\
\hline \multirow[t]{2}{*}{ Employment status } & Not working & 42 & $60.9 \%$ & 0 & $0.0 \%$ & 27 & $39.1 \%$ & \multirow{2}{*}{0.001} \\
\hline & Working & 8 & $9.9 \%$ & 50 & $61.7 \%$ & 23 & $28.4 \%$ & \\
\hline
\end{tabular}


Table 4: Median score of each FSFI domain in study groups and the comparison between the Group I, Group II and Group III in terms of each FSFI domain

\begin{tabular}{|l|l|l|l|l|l|l|}
\hline FSFI domain & & Percentile 25 & Percentile 75 & Median & IQR & p \\
\hline Desire & Group I & 2.4 & 3.6 & 3.0 & 1.2 & 0.347 \\
& Group II & 2.4 & 3.6 & 3.0 & 1.2 & \\
& Group III & 2.4 & 3.6 & 3.3 & 1.2 & \\
\hline Arousal & Group I & 1.5 & 3.9 & 3.0 & 2.4 & $\mathbf{0 . 0 0 1}$ \\
& Group II & 3.0 & 4.8 & 3.9 & 1.8 & \\
& Group III & 2.7 & 4.2 & 3.3 & 1.5 & \\
\hline Lubrication & Group I & 3.0 & 4.8 & 3.9 & 1.8 & $\mathbf{0 . 0 1 2}$ \\
& Group II & 3.9 & 5.7 & 4.8 & 1.8 & \\
& Group III & 3.3 & 5.4 & 4.2 & 2.1 & \\
\hline Orgasm & Group I & 1.6 & 4.4 & 3.6 & 2.8 & $\mathbf{0 . 0 0 1}$ \\
& Group II & 3.6 & 5.6 & 4.4 & 2.0 & \\
& Group III & 3.2 & 4.8 & 3.8 & 1.6 & \\
\hline Satisfaction & Group I & 2.4 & 5.6 & 4.0 & 3.2 & 0.110 \\
& Group II & 4.0 & 5.6 & 4.8 & 1.6 & \\
& Group III & 2.4 & 6.0 & 4.8 & 3.6 & \\
\hline Pain & Group I & 2.4 & 4.8 & 3.6 & 2.4 & $\mathbf{0 . 0 0 1}$ \\
& Group II & 4.0 & 6.0 & 5.0 & 2.0 & \\
& Group III & 2.4 & 4.4 & 3.6 & 2.0 & \\
\hline FSFI & Group I & 15.5 & 25.3 & 22.1 & 9.8 & $\mathbf{0 . 0 0 1}$ \\
& Group II & 22.0 & 29.5 & 26.5 & 7.5 & \\
& Group III & 17.1 & 27.0 & 23.1 & 9.9 & \\
\hline
\end{tabular}

Abbreviation: FSFI. Female Sexual Function Index.

IQR. Interquartile Range

In addition, pregnant women who make up Group 1 were compared according to their gestational weeks. When divided into three groups as first trimester, second trimester and third trimester, there was no statistically significant difference in FSFI scores between the groups (p:0.643), but the highest FSFI score was found in the first trimester. Median FSFI scores of women in the first, second and third trimesters were $24.15,21.50$ and 22.25 respectively.

When the whole questionnaire and its domains, participant age and pregnancy week (for Group I) variables were examined with the Spearman Correlation Analysis, the change in the domains was found to be independent of age and gestational week.

\section{DISCUSSION}

In these days when we are experiencing the COVID-19 pandemic, there have been many physical limitations in our lives along with the pandemic. The social isolation and quarantine process has been the main reason not only for physical limitations but also for psychological impressions. Studies have shown that during the COVID-19 epidemic, overall sexual activity and frequency of sexual intercourse decreased significantly ${ }^{12,13,14}$.

This study compared the FSD rates of women who were pregnant, healthcare workers, women who were not pregnant and not healthcare workers during the COVID-19 pandemic in tertiary hospitals in Turkey.

In studies conducted before the pandemic, the rate of FSD among Turkish women was reported to be about $48 \%{ }^{6,7}$. In the limited number of studies conducted during the Covid -19 pandemic process, it is reported that the FSD rate has increased ${ }^{15}$. In the study by Karakaş et al., the FSD rate in pregnant women during the pandemic period was $87 \%$, and $68 \%$ in non-pregnant women ${ }^{15}$. Similarly, in our study, the FSD rate was found to be $68.7 \%$. When the groups in our study were thinned one by one, the FSD rate in pregnant women was $84 \%, 52 \%$ in health workers and $70 \%$ in the other group.

It is known that sexual functions generally decline during pregnancy. In the studies, the prevalence of FSD in pregnant women is between 50-80\% ${ }^{16-19}$. The FSD rate in Turkish pregnant women was found to be higher in studies and was reported as $80-90 \% 19,20$. The high rates of FSD during 
pregnancy have been attributed to many factors, such as nausea and vomiting in the first trimester, increased vascular congestion in the second trimester, fear of preterm labor, increased abdominal volume in the third trimester. However, when FSD rates are compared according to gestational week in most of the studies, show that sexual function decreased in pregnant women, especially in the third trimester ${ }^{15,16,19}$. In our study, it was found that the rate of FSD in pregnant women was similar to the rates found in Turkish pregnant women before the pandemic, and although there was no statistically significant difference between trimesters, the highest FSFI score was found in the first trimester.

Although we thought that the pandemic process did not cause a significant change in the FSD rate in Turkish pregnant women, it was found in our study that the FSD rates of non-pregnant women during the pandemic period increased. This rate was found to be high in the studies of Karakass et al. which examined the pandemic period and it was reported as $68 \%{ }^{15}$

An important feature that distinguishes our study from previous studies is that healthcare workers are considered as a separate category. We know that this group has been most affected by the pandemic process. Considering the psychological effects of the Covid-19 pandemic, it is predicted that these effects may be more in healthcare workers. In our study, sexual dysfunction was found with a lower rate in female health workers compared to women who were not healthcare workers. This result was actually a bit surprising for us. Whereas Karşıyakalı et al study which included the evaluation of the sexual function in the pandemi, found a decrease in the number of weekly sexual intercourse in those who were healthcare workers. However, this ratio was not evaluated separately for men and women, but reported as a total ${ }^{14}$. Studies conducted before the Covid-19 pandemic also reported high FSD rates in healthcare workers. In a study examining the prevalence of sexual dysfunction in Chinese nurses, 50.99\% FSD rate was found in Chinese nurses and it was reported that this rate was higher than the Chinese female population's FSD rate ${ }^{21}$.

In a study investigating female sexual dysfunction in healthcare workers in Greece, it was reported that sexual dysfunction was found in $69.3 \%$ of healthcare workers. Participants in the study were evaluated in three groups as nurse, medical doctors and hospital administrative employees. It was reported that sexual function screening scores were similar in the nurse and doctor groups and higher than the hospital administrative staff group ${ }^{22}$. In another study conducted in Singapore, nurses were found to have a lower FSD prevalence rate than their other allied health counterparts (Rehabilitation, Nutrition and Dietetics, Medical Social Services and Pharmacy) ${ }^{23}$.

When we examined the reasons for our study result, we identified several possible factors. The first of these is that our study was carried out in a university hospital and our hospital was not a pandemic hospital. Therefore, the effects of the pandemic process may have been less on hospital staff. Second, the education level of all healthcare workers is above university and graduate. Many studies have shown that sexual dysfunction is less common in working women and women with a high level of education ${ }^{7,19,24}$. In our study, while almost all healthcare workers are university graduates, in the groups of women who are pregnant and not healthcare workers' women have an education level of university is $30 \%$. At the same time, $62 \%$ of working women in the study consist of healthcare workers, while pregnant women make up 10\% and Group III women make up 28\%. In addition, although there are publications reporting that advanced female age, menopausal period, and smoking increase female sexual dysfunction ${ }^{6,7,25,26}$ there are studies that do not find a relationship, as in our study ${ }^{23,27}$.

The factors affecting the domains of FSFI were examined in our study, women who were working, have educational status university and above, were found to have less arousal problems, less problems in reaching orgasm, and less sexual pain. Similarly, Laumann et al. reported in their study that women who were university graduates experienced less sexual desire, orgasm problems, sexual pain, and sexual anxiety than women who did not graduate from high school ${ }^{28}$. And also, in our study, it was observed that delivery methods did not affect the FSFI total score, but it affects one of its domains, sexual pain. It was found that those who delivered vaginally had more sexual pain. However, many studies have reported that delivery methods do not affect sexual dysfunction 29,30. Also, one study found that women who delivered via cesarean section tended to be less painful and more satisfied during sexual intercourse at postpartum 3 months compared to women who had vaginal delivery with media lateral episiotomy. But, there were no differences between delivery methods in any of the FSFI domains at 6, 12, and 24 months ${ }^{31}$.

\section{Strengths and limitations}

This is the first study to compare the female sexual dysfunction in healthcare workers to pregnant and non-pregnant, non-healthcare worker's women in 
Turkey. This study to understand the prevalence of FSD in female population with different characteristics and examined the factors that may affect FSD, has sufficient sample size for analysis.

Although it was cross-sectional and had a sufficient sample size, our study had some limitations. The first of these is that it may be insufficient to reflect the whole of society due to the fact that it is a single center study. Second, while evaluating the prevalence of FSD, sexual function of their partners were not collected. It should not be forgotten that male sexual dysfunction may be among the causes of female sexual dysfunction. Not being able to evaluate the male factor may have prevented us from reaching real FSD rates.

\section{CONCLUSION}

A cross-sectional study in a tertiary hospital found a high prevalence $(68.7 \%)$ of sexual dysfunction in Turkish women during the COVID-19 pandemic. The highest FSD rate was found in pregnant women in a present study. However, this high rate was not different from the rate found in Turkish pregnant women before the pandemic. It was observed that sexual dysfunction increased especially in non-pregnant women during the pandemic period. Surprisingly, the FSFI score of healthcare women was higher than the pregnant and general female population. This situation led to the prediction that women with a high level of education and employment were less affected by sexual dysfunction during the pandemic period.

\section{Acknowledgments}

We greatly appreciate Selim Çam (Statistician,PhD) for the help in the statistical analysis of the study.

Ethics Committee Approval: This study was approved by Human Research Ethics Committee of Sivas Cumhuriyet University (registry no: 202011/10). All procedures in this study involving human participants were performed in accordance with the 1964 Helsinki Declaration and its later amendments.

\section{REFERENCES}

1. Dhama K, Sharun K, Tiwari R, Dadar M, Malik YS, Singh KP, Chaicumpa W. COVID19, an emerging coronavirus infection: advances and prospects in designing and developing vaccines, immunotherapeutics, and therapeutics. Hum Vaccin Immunother. 2020; 16(6):1232 1238.

2. Kazan Kizilkurt O, Dilbaz N, Noyan CO. Psychological Impact of COVID-19 Pandemic on General Population in Turkey:
Risk Factors. Asia Pac J Public Health. 2020 ;32(8):519

3. American College of Obstetricians and Gynecologists' Committee on Practice Bulletins-Gynecology. Female Sexual Dysfunction: ACOG Practice Bulletin Clinical Management Guidelines for Obstetrician-Gynecologists, Number 213. Obstet Gynecol. 2019;134(1): e1-e18.

4. Reddy RM, Saravanan RA, Praharaj SK, Thirunavukarasu M. Sexual Dysfunction in Women with Depression: A Hospital-Based Cross-sectional Comparative Study. Indian J Psychol Med. 2020 6;42(1):46-51.

5. Shifren JL, Monz BU, Russo PA, Segreti A, Johannes CB. Sexual problems and distress in United States women: prevalence and correlates. Obstet Gynecol 2008; 112:970-8. (Level II-3)

6. Oksuz E, Malhan S. Prevalence and risk factors for female sexual dysfunction in Turkish women. J Urol. 2006;175(2):654-8; discussion 658.

7. Cayan S, Akbay E, Bozlu M, Canpolat B, Acar D, Ulusoy E. The prevalence of female sexual dysfunction and potential risk factors that may impair sexual function in Turkish women. Urol Int. 2004;72(1):52-7.

8. Rosen R, Brown C, Heiman J, Leiblum S, Meston C, Shabsigh R, Ferguson D, D'Agostino R Jr. The Female Sexual Function Index (FSFI): A multidimensional self-report instrument for the assessment of female sexual function. J Sex Marital Ther.2000; 26: 191208.

9. Oksuz E, Malhan S: Kadın cinsel fonksiyon indeksi: Türkçe uyarlamasının geçerlilik ve güvenilirlik analizi Sendrom,2005;17: 54-60.

10. Wiegel M, Meston C, Rosen R: The female sexual function index (FSFI): cross-validation and development of clinical cutoff scores. $\mathbf{J}$ Sex Marital Ther. 2005;31: 1-20.

11. Enstitüsü, Hacettepe Üniversitesi Nüfus Etütleri. "Türkiye Nüfus ve Sağl1k Araştırması (2018)."

12. Li W, Li G, Xin C, Wang Y, Yang S. Challenges in the Practice of Sexual Medicine in the Time of COVID-19 in China. J Sex Med. 2020;17(7):1225-1228

13. Cito G, Micelli E, Cocci A, Polloni G, Russo GI, Coccia ME, Simoncini T, Carini M, Minervini A, Natali A. The Impact of the 
COVID-19 Quarantine on Sexual Life in Italy. Urology. 202;147:37-42.

14. Karsiyakali N, Sahin Y, Ates HA, Okucu E, Karabay E. Evaluation of the Sexual Functioning of Individuals Living in Turkey During the COVID-19 Pandemic: An Internet-Based Nationwide Survey Study. Sex Med. 2020 26;9(1):100279.

15. Karakas LA, Azemi A, Simsek SY, Akilli H, Esin S. Risk factors for sexual dysfunction in pregnant women during the COVID-19 pandemic. Int $\mathrm{J}$ Gynaecol Obstet. 2021;152(2):226-230.

16. Bartellas E, Crane JM, Daley M, Bennett KA, Hutchens D. Sexuality and sexual activity in pregnancy. BJOG. 2000;107(8):964-8.

17. Ahmed MR, Madny EH, Sayed Ahmed WA. Prevalence of female sexual dysfunction during pregnancy among Egyptian women. J Obstet Gynaecol Res. 2014;40(4):1023-9.

18. Naldoni LM, Pazmiño MA, Pezzan PA, Pereira SB, Duarte G, Ferreira CH. Evaluation of sexual function in Brazilian pregnant women. J Sex Marital Ther. 2011;37(2):11629.

19. Küçükdurmaz F, Efe E, Malkoç Ö, Kolus E, Amasyalı AS, Resim S. Prevalence and correlates of female sexual dysfunction among Turkish pregnant women. Turk J Urol. 2016;42(3):178-83.

20. Aydin M, Cayonu N, Kadihasanoglu M, Irkilata L, Atilla MK, Kendirci M. Comparison of Sexual Functions in Pregnant and Non-Pregnant Women. Urol J. 2015 14;12(5):2339-44.

21. Yang YQ, Xu Q, Tong WJ, Gao CL, Li HM. Sexual Dysfunction among Chinese Nurses: Prevalence and Predictors. Biomed Environ Sci. 2017;30(3):229-234.

22. Stamatiou K, Margariti M, Nousi E, Mistrioti D, Lacroix R, Saridi M. Female Sexual Dysfunction (Fsd) In Women Health Care Workers. Mater Sociomed. 2016;28(3):17882.

23. Safdar F, Eng CLJ, Wai KL, Tey WS, Ang SB. Prevalence of female sexual dysfunction in allied health workers: a cross-sectional pilot study in a tertiary hospital in Singapore. BMC Womens Health. 2019; 14;19(1):137.

24. Astepe BS, Köleli I. A cross-sectional study of female sexual dysfunction among Turkish pregnant and nonpregnant women: correlation with hormone profile. The European Research Journal. 2018.

25. Aggarwal RS, Mishra VV, Panchal NA, Patel NH, Deshchougule VV, Jasani AF. Sexual dysfunction in women: an overview of risk factors and prevalence in Indian women. JSAFOG. 2012;4(3):134-6.

26. Jaafarpour M, Khani A, Khajavikhan J, Suhrabi Z. Female sexual dysfunction: prevalence and risk factors. J Clin Diagn Res. 2013;7(12):2877-80.

27. McCool-Myers M, Theurich M, Zuelke A, Knuettel H, Apfelbacher C. Predictors of female sexual dysfunction: a systematic review and qualitative analysis through gender inequality paradigms. BMC Womens Health. 2018; 22;18(1):108.

28. Laumann EO, Paik A, Rosen RC. Sexual dysfunction in the United States: prevalence and predictors. JAMA. 1999 Feb 10;281(6):537-44. doi: 10.1001/jama.281.6.537. Erratum in: JAMA 1999 7;281(13):1174.

29. Saotome TT, Yonezawa K, Suganuma N. Sexual Dysfunction and Satisfaction in Japanese Couples During Pregnancy and Postpartum. Sex Med. 2018;6(4):348-355.

30. Ghorat F, Esfehani RJ, Sharifzadeh M, Tabarraei Y, Aghahosseini SS. Long term effect of vaginal delivery and cesarean section on female sexual function in primipara mothers. Electron Physician. 2017 25;9(3):3991-3996.

31. Kahramanoglu I, Baktiroglu M, Hamzaoglu K, Kahramanoglu O, Verit FF, Yucel O. The impact of mode of delivery on the sexual function of primiparous women: a prospective study. Arch Gynecol Obstet. 2017;295(4):907-916. 